\title{
ANALISIS PENGARUH GOOD CORPORATE GOVERNANCE DAN INTELLECTUAL CAPITAL DISCLOSURE TERHADAP EARNING RESPONSE COEFFICIENT \\ (Studi Pada Perbankan Yang Listed di Bursa Negara ASEAN Tahun 2015-2016)
}

\section{${ }^{1}$ Erwindiawan}

${ }^{1}$ Universitas Islam Syekh Yusuf Tangerang

Email:erwindiawan@gmail.com

\begin{abstract}
This study aims to determine the effect of Good Corporate Governance and Intellectual Capital Disclosure as independent variable on Earning Response Coefficient as dependent variable with control variable Size, Leverage and Growth.The populations in this research were banking sector companies in ASEAN (Indonesia, Singapura, Malaysia, Thailand and Philipine) and ASEAN CG Scorecard assesment in the period 2015-2016. By using purpose sampling method obtained 73 sample. The method used in this study is causal research methods and from 73 banking companies are used as the samples of this study with the specified criteria. The statistical method being used is multiple linear regression with SPSS software. The result shows that : 1) Good corporate governance has effect on Earning Response Coefficient, 2) Intellectual Capital Disclosure has effect on Earning Response Coefficient.
\end{abstract}

Keywords: Good Corporate Governance, Intellectual Capital Disclosure, Earning Response Coefficient, Size, Leverage, Growth. 


\section{A. PENDAHULUAN}

Earnings response coefficient (ERC) merupakan salah satu ukuran atau proksi yang digunakan untuk mengukur kualitas laba. ERC merupakan model penilaian yang dapat digunakan untuk mengindikasikan kemungkinan naik turunnya harga saham atas reaksi pasar terhadap informasi laba yang diumumkan oleh perusahaan. Kuatnya reaksi pasar terhadap informasi laba akan tercermin dengan tingginya ERC (kualitas laba perusahaan tinggi), demikian sebaliknya (Sayekti dan Sensi, 2007).

Pelaksanaan Good Corporate Governance (GCG) sangat diperlukan untuk memenuhi kepercayaan masyarakat dan dunia internasional sebagai syarat mutlak bagi dunia perindustrian untuk berkembang dengan baik dan sehat yang tujuan akhirnya untuk mewujudkan stakeholder value.

Variabel selanjutnya adalah intellectual capital disclosure. Modal intelektual (intellectual capital) sebuah strategi bisnis yang didasarkan pada tenaga kerja (labor based business) menuju knowledge based business (bisnis berdasarkan pengetahuan), sehingga karakteristik utama perusahaanya menjadi perusahaan yang memiliki tenaga kerja yang berpengetahuan. Modal intelektual (intellectual capital) menjadi perhatian karena manfaat dari intellectual capital sebagai alat untuk menentukan nilai perusahaan.

Earnings Response Coefficient (ERC) dari setiap sekuritas berbedabeda besarannya dikarenakan terdapat banyak faktor yang mempengaruhi ERC suatu sekuritas. Dalam penelitian ini, penelitian mencoba meneliti melihat pengaruh ERC melalui Corporate Governance dan Intellectual Capital Disclosure.

\section{B. TELAAH LITERATUR DAN PENGEMBANGAN HIPOTESIS Teori Agensi}

Agency cost adalah biaya yang dikeluarkan untuk memonitoring agar agent tidak akan mengambil tindakan tertentu yang akan membahayakan principal atau biaya untuk memastikan bahwa principal akan diberi kompensasi jika agent tidak mengambil tindakan yang membahayakan bagi principal dan pengurangan kesejahteraan yang dialami oleh principal sebagai akibat dari perbedaan keputusan yang diambil agent dengan keputusan untuk memaksimalkan keuntungan bagi principal. Menurut Jensen and Meckling (1976) agency cost terdiri dari :

1. The monitoring expenditures by the principal.

Biaya yang dikeluarkan untuk mengawasi dan memonitoring kinerja agent dalam mengelola perusahaan.

15|Pelita - Jurnal Penelitian dan Karya Ilmiah 
ANALISIS PENGARUH GOOD CORPORATE GOVERNANCE DAN INTELLECTUAL CAPITAL DISCLOSURE TERHADAP EARNING RESPONSE COEFFICIENT (Studi Pada Perbankan Yang Listed di Bursa Negara ASEAN Tahun 2015-2016)

\section{Erwindiawan}

2. The bonding expenditures by the agent.

Biaya untuk memastikan bahwa principal akan diberi kompensasi jika agent tidak mengambil tindakan yang membahayakan bagi principal. Biaya ini timbul karena dilakukannya pembatasan-pembatasan bagi kegiatan agent oleh principal.

3. The residual loss

Pengurangan kesejahteraan yang dialami oleh principal sebagai akibat dari perbedaan keputusan yang diambil agent dengan keputusan untuk memaksimalkan keuntungan bagi principal.

Salah satu cara untuk meminimalkan Agency Problem adalah dengan menerapkan mekanisme Good Corporate Governance dalam pengawasan kinerja perusahaan. Dengan menerapkan Good Corporate Governance diharapkan direksi akan bertindak untuk kepentingan stakeholder dan shareholder sehingga hal tersebut mengurangi asimetri informasi, menurunkan agency cost dan dapat meningkatkan pengungkapan perusahaan.

\section{Teori Signaling}

Signaling Theory berkaitan dengan Agency Theory dalam hal pengungkapan informasi. Dalam agency theory dijelaskan bahwa hubungan keagenan dapat menimbulkan asimetri informasi, sehingga diperlukan pengungkapan untuk memberikan signal dari agent kepada principal. Teori ini menekankan pentingnya informasi yang dikeluarkan oleh perusahaan terhadap keputusan investasi pihak di luar perusahaan. Teori signal menunjukkan bahwa perusahaan dengan kinerja yang unggul menggunakan informasi keuangan untuk mengirim signal ke pasar (Ross, 1976; Spence, 1974).

Menurut Sharpe (1997), pengumuman informasi keuangan memberikan signal bahwa perusahaan mempunyai prospek yang baik di masa mendatang (good news). Implikasinya investor akan tertarik untuk menanamkan modal dan berinvestasi di perusahaan, dengan demikian, pengungkapan informasi keuangan suatu perusahaan dapat mempengaruhi keputusan pasar.

\section{Teori Stakeholder}

Teori Stakeholder menekankan pentingnya untuk mempertimbangkan kepentingan, kebutuhan, dan pengaruh dari pihak pihak yang terkait dengan kebijakan dan kegiatan operasi perusahaan, terutama dalam hal pengambilan keputusan perusahaan. Konsep 
Stakeholder merupakan generalisasi dari gagasan pemegang saham, dimana mereka memiliki beberapa klaim khusus pada perusahaan. Hanya pemegang saham yang memiliki hak untuk menuntut atas tindakan tertentu yang dilakukan manajemen, begitu juga para stakeholders lainnya memiliki hak untuk mengajukan klaim (Freeman, 1984).

Tujuan utama dari teori stakeholder adalah untuk membantu manajer korporasi mengerti lingkungan stakeholder mereka dan melakukan pengelolaan dengan lebih efektif diantara keberadaan hubunganhubungan dilingkungan perusahaan mereka. Tujuan yang lebih luas dari teori stakeholder adalah untuk menolong manajer korporasi dalam meningkatkan nilai dari dampak aktifitas-aktifitas mereka, dan meminimalkan kerugian-kerugian bagi stakeholder (Ulum, 2009:5).

\section{Teori Legitimasi}

Legitimasi Teori menegaskan bahwa perusahaan berusaha untuk memastikan mereka beroperasi dalam batas dan norma masyarakat agar kegiatan mereka terakui oleh masyarakat. Perusahaan mencoba untuk mengelola legitimasi mereka karena dapat membantu memastikan masuknya modal, tenaga kerja dan pelanggan yang diperlukan untuk kelangsungan hidup perusahaan. Hal ini juga mencegah regulasi pemerintah yang terjadi akibat ketiadaan legitimasi, dan mencegah pemboikotan produk serta tindakan mengganggu lainnya oleh pihak eksternal. Dengan mengurangi masalah-masalah potensial ini, legitimasi organisasi memberikan manajer otonomi untuk memutuskan bagaimana dan di mana bisnis akan dilakukan (Neu et al.,1998).

Lindblom (1993) mengusulkan empat strategi komunikasi yang manajemen dapat melakukan untuk mencapai atau mempertahankan legitimasi:

a. Berusaha untuk mendidik dan menginformasikannya kepada stakeholder tentang perubahan dalam kinerja dan kegiatan organisasi.

b. Mencoba untuk mengubah persepsi stakeholder tanpa mengubah perilaku organisasi.

c. Mencoba untuk memanipulasi persepsi Stakeholder dengan mengalihkan perhatian atas isu tertentu kepada isu yang berkaitan lainnya.

d. Mencoba untuk mengubah harapan eksternal dari kinerja organisasi. 
ANALISIS PENGARUH GOOD CORPORATE GOVERNANCE DAN INTELLECTUAL CAPITAL DISCLOSURE TERHADAP EARNING RESPONSE COEFFICIENT (Studi Pada Perbankan Yang Listed di Bursa Negara ASEAN Tahun 2015-2016)

\section{Erwindiawan}

4. Good Corporate Governance

\section{Definisi Corporate Governance}

Menurut FCGI (Forum for Corporate Governance in Indonesia) Corporate Governance didefinisikan sebagai:

"a set of rules that define the relationship between shareholders, managers, creditors, the government, employees and other internal and external stakeholders in respect to their rights and responsibilities, or the system by which companies are directed and controlled."

The Institute Indonesia of Corporate Governance (IICG, 2006), mendefinisikan Corporate Governance (CG), yaitu: “Corporate Governance (CG) sebagai serangkaian mekanisme untuk mengarahkan dan mengendalikan suatu perusahaan agar operasional perusahaan berjalan sesuai dengan harapan para pemangku kepentingan (stakeholders). CG merupakan mekanisme monitoring aktivitas perusahaan agar tindakan manajerial (agen) sejalan dengan tujuan perusahaan (prinsipal) yaitu meningkatkan nilai perusahaan."

\section{Pengukuran Good Corporate Governance}

Salah satu penilaian Corporate Governance adalah menggunakan Asean Corporate Governance Scorecard, yang merupakam suatu tolak ukur atau parameter pengukuran praktek Corporate Governance yang disepakati oleh ACMF (ASEAN Capital Market Forum) yaitu asosiasi otoritas pasar modal ASEAN, dimana ASEAN Corporate Governance Scorecard tersebut dibuat berdasarkan OECD Principles dan diharapkan dapat meningkatkan kepercayaan investor kepada perusahaan-perusahaan listing di ASEAN. Instrumen penilaian mengacu pada prinsip-prinsip Corporate Governance yang dikembangkan oleh OECD meliputi (1) Hak-hak pemegang saham (Rights of Shareholders); (2) Perlakuan yang Setara Terhadap Pemegang Saham (Equitable Treatment of Shareholders); (3) Peran Pemangku Kepentingan (Role of Stakeholders); (4) Pengungkapan dan Transparansi (Disclosure and Transparency); dan (5) Tanggung Jawab Dewan (Responsibilities of Boards). Kelima prinsip-prinsip tersebut dijabarkan secara komprehensif ke dalam 179 pertanyaan.

\section{Intellectual Capital}

\section{Definisi Intellectual Capital}

Brooking (1996) menyatakan bahwa intellectual capital adalah istilah yang diberikan kepada kombinasi dari aset tak berwujud, properti intelektual, karyawan, dan infrastruktur yang memungkinkan perusahaan

18|Pelita - Jurnal Penelitian dan Karya Ilmiah 
untuk dapat berfungsi. Dalam definisi ini jelas tersirat bahwa modal intelektual tidak hanya sekedar tentang sumber daya manusia (human capital/HC), HC hanyalah salah satu komponen dari modal intelektual.

Roos et al. (1997) menyatakan bahwa modal intelektual meliputi seluruh proses dan aset yang tidak secara normal yang nampak di neraca dan semua intangible assets (trademarks, patent, dan brands) yang menjadi perhatian metode akuntansi modern. Sedangkan Bontis (1998) mengakui bahwa modal intelektual adalah elusive, namun ketika modal intelektual dapat ditemukan dan dieksploitasi, maka ia akan menjadi sumber daya baru bagi organisasi untuk dapat memenangkan persaingan.

Organisation for Economic Co-operation and Development (OECD, 1999) menyebut modal intelektual sebagai nilai ekonomi dari dua kategori aset tak berwujud: (1) organizational (structural) capital; dan (2) human capital. Lebih tepatnya, organisational (structural) capital mengacu pada hal seperti sistem software, jaringan distribusi, dan rantai pasokan. Human capital meliputi sumber daya manusia di dalam organisasi (yaitu sumber daya tenaga kerja/karyawan) dan sumber daya eksternal yang berkaitan dengan organisasi, seperti konsumen dan supplier.

Dalam PSAK Nomor 19 tahun 2009 tentang aset tak berwujud, telah disebutkan bahwa modal intelektual merupakan kategori intangible asset. Namun beberapa intangible asset seperti goodwill, yaitu merk dagang yang dihasilkan perusahaan tidak boleh diakui sebagi intangible asset. Oleh karena itu, pengungkapan informasi mengenai modal intelektual atau intellectual capital bersifat sukarela, mengingat PSAK Nomor 19 belum mengatur tentang modal intelektual baik dari cara pengidentifikasiannya maupun dari segi pengukurannya. Kriteria untuk memenuhi definisi intangible assets antara lain dapat diidentifikasi, adanya pengendalian sumber daya dan adanya manfaat ekonomis masa depan.

\section{Komponen Intellectual Capital}

Bontis et al. (2000) menyatakan bahwa secara umum, para peneliti mengidentifikasikan tiga konstruk utama dari modal intelektual, yaitu human capital (HC), structural capital (SC), dan customer capital (CC). Menurut Bontis et al. (2000), secara sederhana HC mempresentasikan individual knowledge stock suatu organisasi yang direpresentasikan oleh karyawannya. HC merupakan kombinasi dari genetic inheritance; education; experience, and attitude tentang kehidupan dan bisnis. SC meliputi seluruh non-human storehouses of knowledge dalam organisasi. Termasuk dalam hal ini adalah database, organizational charts, process manuals, strategies, routines, dan segala hal yang membuat nilai perusahaan lebih besar daripada nilai materialnya.

19|Pelita - Jurnal Penelitian dan Karya Ilmiah 
ANALISIS PENGARUH GOOD CORPORATE GOVERNANCE DAN INTELLECTUAL

CAPITAL DISCLOSURE TERHADAP EARNING RESPONSE COEFFICIENT

(Studi Pada Perbankan Yang Listed di Bursa Negara ASEAN Tahun 2015-2016)

Erwindiawan

Sedangkan tema utama dari CC adalah pengetahuan yang melekat dalam marketing channels dan customer relationship dimana suatu organisasi mengembangkannya melalui jalannya bisnis.

Lev (2001) menyakan bahwa modal intelektual merupakan fungsi dari empat tipe aset, yaitu: (1) market assets, (2) intellectual property assets, (3) human-centered assets, dan (4) infrastructure assets.

\section{Intellectual Capital Disclosure}

Perusahaan-perusahaan melakukan pengungkapan modal intelektual karena berbagai alasan. Menurut Widjanarko (2006) lima alasan perusahaan-perusahaan melaporkan modal intelektual yaitu:

1. Pelaporan modal intelektual dapat membantu organisasi merumuskan strategi bisnis. Dengan mengidentifikasi dan mengembangkan modal intelektual suatu organisasi untuk mendapatkan competitive advantage.

2. Pelaporan modal intelektual dapat membawa pada pengembangan indikator-indikator kunci prestasi perusahaan yang akan membantu mengevaluasi hasil-hasil pencapaian strategi.

3. Pelaporan modal intelektual dapat membantu mengevaluasi merger dan akuisisi perusahaan, khususnya untuk menentukan harga yang dibayar oleh perusahaan pengakuisisi.

4. Menggunakan pelaporan modal intelektual nonfinancial dapat dihubungkan dengan rencana intensif dan kompensasi perusahaan. Alasan pertama sampai dengan keempat, merupakan alasan internal dari perusahaan dalam melaporkan modal intelektual.

5. Alasan ini merupakan alasan eksternal perusahaan yaitu mengkomunikasikan pada stakeholder eksternal tentang intellectual property yang dimiliki perusahaan.

Modal intelektual sekarang ini dianggap sebagai faktor kesuksesan bagi suatu organisasi dan karenanya akan semakin menjadi perhatian dalam kajian strategi organisasi dan strategi pembangunan. Di abad ini, komunitas bisnis seluruh dunia sepakat bahwa knowledge asset menjadi sangat penting dalam pengkreasian nilai perusahaan dari pada faktor produksi fisik (Saleh et al, 2007).

\section{Pengukuran Intellectual Capital Disclosure}

Pengukuran pengungkapan modal intelektual dalam penelitian ini menggunakan 61 item indeks pengungkapan yang dikembangkan oleh Li, et al (2008). 
Indeks pengungkapan merupakan suatu metode untuk membuat angka pengungkapan informasi tertentu yang menggunakan 1 untuk yang melakukan pengungkapan dan 0 untuk yang tidak mengungkapkan pada masing-masing item (Oktavianti dan Wahidahwati, 2014). Prosentase dari index pengungkapan sebagai total dihitung menurut rumusan sebagai berikut:

$$
\text { Score }=\left(\sum_{i=1}^{m} d_{i} / M\right) \times 100 \%
$$

Keterangan:

Score $=$ variabel dependen indeks pengungkapan intellectual capital (ICD Index)

Di = nilai 1 jika item $i$ ditemukan dan 0 jika tidak ditemukan

$\mathrm{M} \quad=$ total jumlah item yang diukur (61 item)

\section{Earning Response Coefficient}

\section{Definisi Earning Response Coefficient}

Earnings response coefficient (ERC) dapat didefinisikan sebagai efek satu satuan mata uang dari laba yang diharapkan pada return saham dan menggambarkan reaksi investor terhadap pengumuman laba atau rugi tersebut. ERC menunjukkan kuat lemahnya reaksi pasar terhadap pengumuman laba, sehingga dapat digunakan untuk memprediksi kandungan dalam informasi laba. Jika investor mempunyai persepsi bahwa informasi keuangan itu memiliki kredibilitas tinggi, maka ia akan bereaksi terhadap laporan keuangan tersebut secara kuat (Tiolemba, 2008).

Tingginya earnings response coefficient (ERC) terlihat dari kuatnya reaksi pasar terhadap informasi laba. Demikian pula sebaliknya, rendahnya earnings response coefficient (ERC) tercermin dari lemahnya reaksi pasar terhadap informasi laba, hal ini menunjukkan bahwa laba yang dilaporkan kurang berkualitas. Laba yang baik didukung juga oleh penerapan sistem tata kelola yang baik (good corporate governance) suatu perusahaan, sehingga keinformatifan laba juga akan semakin kuat. Corporate governance merupakan kebijakan yang mengatur hubungan antara manejemen perusahaan kepada pihak internal perusahaan dengan pihak eksternal perusahaan.

Yang berarti, earning response coefficient (ERC) mengukur sejauh mana pengembalian abnormal suatu sekuritas dalam merespon komponen laba yang tidak diprediksikan. Menurut Cho dan Jang (1991) 
mendefinisikan earning response coefficient sebagai efek setiap dolar dari laba kejutan (unexpected earnings) terhadap return saham, yang ditunjukkan melalui slope koefisien dalam regresi abnormal return saham dengan unexpected earnings. Dengan kata lain ERC merupakan koefisien sensitivitas perubahan harga saham terhadap perubahan laba akuntansi.

\section{Pengukuran Earning Response Coefficient}

Besarnya earnings response coefficient diperoleh dengan melakukan beberapa tahap perhitungan. Tahap pertama menghitung cumulative abnormal return (CAR) masing-masing sampel dan tahap kedua menghitung unexpected earnings (UE) sampel. Tahap-tahap dalam menghitung ERC sebagai berikut:

a. Cummulative Abnormal Return (CAR) Penelitian ini mengukur return abnormal tiga hari di sekitar tanggal publikasi dan pada tanggal publikasi laporan keuangan ( $\mathrm{t}-3, \mathrm{t}+3)$. Perhitungan Akumulasi Return Tidak Normal (ARTN) atau Cummulative Abnormal Return (CAR) untuk masing-masing perusahaan merupakan akumulasi dari ratarata abnormal return selama periode jendela dengan menggunakan rumus berikut ini:

$$
\operatorname{ARTN}_{\text {i.t }}=\sum_{\mathrm{a}=\mathrm{t} 3}^{\mathrm{t}} \mathrm{RTN}_{\mathrm{i} . \mathrm{a}}
$$

Sumber: Jogiyanto (2007: 450)

Keterangan untuk penelitian ini:

ARTNi.t: Akumulasi Return Tidak Normal (cummulative abnormal return) sekuritas i pada waktu $\mathrm{t}$, yang diakumulasi dari return tidak normal (RTN) sekuritas ke-i mulai hari awal periode peristiwa (t3) sampai hari ke-t

RTN i.a: Return tidak normal (abnormal return) untuk sekuritas ke-i pada hari ke-a, yaitu mulai 3 (hari awal periode jendela) sampai hari ke-t.

Abnormal return (Soewardjono, 2005) diperoleh dari :

$$
R A_{i t}=R_{i t}-R_{m t}
$$

Keterangan:

RAit= Return abnormal perusahaan i pada waktu $\mathrm{t}$

Rit= Return perusahaan i pada waktu $\mathrm{t}$

$\mathrm{Rmt}=$ Return pasar pada waktu $\mathrm{t}$ 
Untuk memperoleh data abnormal return, terlebih dahulu harus mencari return saham harian dan return pasar harian

1) Return saham harian dihitung dengan rumus:

Keterangan:

$$
R_{i t}=\frac{\left(P_{i t}-P_{i t-1}\right)}{P_{i t-1}}
$$

Rit= Return saham perusahaan i pada hari $\mathrm{t}$

Pit= Harga penutupan saham i pada hari $t$

Pit-1= Harga penutupan saham I pada hari t-1

2) Return pasar harian dihitung sebagai berikut:

$$
R_{m t}=\frac{I H S G_{t}-I H S G_{t-1}}{I H S G_{t-1}}
$$

Keterangan:

Rmt $=$ Return pasar harian

IHSGt $=$ Indeks harga saham gabungan pada hari $t$

IHSGt-1= Indeks harga saham gabungan pada hari t-1

b. Unexpected earnings diukur menggunakan pengukuran laba per lembar saham (Riyatno, 2007):

Keterangan:

$$
\mathrm{UE}_{\mathrm{It}}=\frac{\mathrm{EPS}_{\mathrm{t}}-\mathrm{EPS}_{\mathrm{t}-1}}{\mathrm{EPS}_{\mathrm{t}-1}}
$$

UEit $=$ Unexpected earnings perusahaan i pada periode (tahun) $\mathrm{t}$ EPSit $=$ Laba akuntansi perusahaan i pada periode (tahun) $t$ EPSit-1= Laba akuntansi perusahaan i pada periode (tahun) sebelumnya

c. Earnings Response Coefficient (ERC) akan dihitung dari slope b pada hubungan CAR dengan UE (Teets and Wasley 1996) yaitu :

$$
\mathrm{CAR}_{\mathrm{it}}=\mathrm{a}+\mathrm{bUE} \mathrm{E}_{\mathrm{it}}+\varepsilon_{\mathrm{it}}
$$

Keterangan:

CARit: Abnormal return kumulatif perusahaan i selama perioda pengamatan +3 hari dari publikasi laporan keuangan

UEit: Unexpected earnings

ci: Komponen error dalam model atas perusahaan i pada perioda $t$

\section{Variabel Kontrol}


ANALISIS PENGARUH GOOD CORPORATE GOVERNANCE DAN INTELLECTUAL

CAPITAL DISCLOSURE TERHADAP EARNING RESPONSE COEFFICIENT

(Studi Pada Perbankan Yang Listed di Bursa Negara ASEAN Tahun 2015-2016)

Erwindiawan

Variabel kontrol digunakan untuk mengontrol hubungan antara variabel bebas dengan variabel terikat, karena variabel control diduga ikut berpengaruh terhadap variabel bebas.

Size

Dalam penelitian ini, ukuran perusahaan dihitung berdasarkan nilai natural $\log (\ln )$ dari total asset perusahaan pada akhir tahun, karena ln total asset lebih stabil dan representatif dalam menunjukan ukuran perusahaan (Ardi dan Lana, 2007). Total asset bisa dijadikan proksi ukuran (size) perusahaan karena total asset mencakup asset lancar dan tidak lancar yang digunakan oleh perusahaan, sehingga lebih merepresentasikan ukuran perusahaan yang sebenarnya (Oktavianti dan Wahidahwati, 2014).

Size dirumuskan sebagai berikut (Waryanto, 2010):

\section{Leverage}

\section{$\mathrm{SIZE}=\log ($ nilai buku total aset $)$}

Menurut Belkaoui dan Karpik (1989) dalam Sembiring (2005: 382) keputusan untuk mengungkapkan informasi sosial akan mengikuti suatu pengeluaran untuk pengungkapan yang menurunkan pendapatan. Sesuai dengan teori agensi maka manajemen perusahaan dengan tingkat leverage yang tinggi akan mengurangi pengungkapan tanggung jawab social yang dibuatnya agar tidak menjadi sorotan dari para debtholders. Pengukuran leverage ini mengacu pada penelitian yang telah dilakukan oleh Susanto (2012). Rumus yang digunakan untuk mengukur variabel leverage adalah:

\section{Growth}

$$
\text { LEVit }=\frac{\text { TUit }}{\text { TAit }}
$$

Pada penelitian ini kesempatan bertumbuh di ukur dengan market to book value of equity ratio. Sebagaimana menurut Bekaert et al. (2004) dalam Wahyudianawati (2005), menyatakan bahwa market to book value of equity ratio merupakan proksi yang sering digunakan untuk mengukur variabel kesempatan bertumbuh.

$$
\text { Market to Book Value Ratio }=\frac{\text { Nilai Pasar Ekuitas }}{\text { Nilai Buku Ekuitas }}
$$




\section{Kerangka Pemikiran}

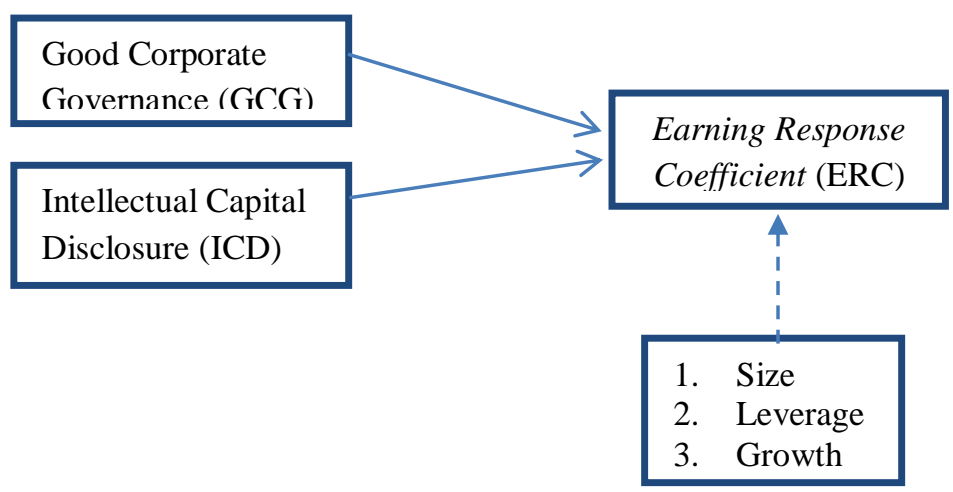

\section{Hipotesis}

1. Good Corporate Governance berpengaruh positif terhadap Earning Response Coefficient dengan variabel kontrol Size, Leverage dan Growth.

2. Intellectual Capital Disclosure berpengaruah positif terhadap Earning Response Coefficient dengan variabel kontrol Size, Leverage dan Growth.

\section{METODE PENELITIAN}

Teknik pengambilan sampel yang digunakan dalam penelitian ini adalah teknik purposive sampling.

Kriteria penentuan sampel dalam penelitian ini adalah:

1. Perusahaan perbankan yang terdaftar di Bursa Negara ASEAN berturut-turut selama periode pengamatan.

2. Perusahaan perbankan yang terdaftar di Bursa Negara ASEAN tidak mengalami merger selama periode pengamatan.

3. Perusahaan perbankan yang terdaftar di Bursa Negara ASEAN yang yang tidak mengalami kerugian selama periode pengamatan.

4. Perusahaan perbankan yang terdaftar di Bursa Negara ASEAN yang menerbitkan annual report dan men-disclose Corporate Governance Scorecard ASEAN dan Intellectual Capital dengan lengkap dan konsisten berturut-turut selama periode pengamatan.

Data yang digunakan dalam penelitian ini adalah data sekunder. Teknik yang digunakan peneliti yaitu dengan mengumpulkan data sekunder yang berkaitan dengan penelitian ini, data berupa catatan, laporan keuangan maupun informasi lainnya yang diperoleh melalui Bursa Negara ASEAN, website www.idx.com dan Website perusahaan perbankan yang digunakan dalam penelitian. Teknik lainnya yaitu research 
ANALISIS PENGARUH GOOD CORPORATE GOVERNANCE DAN INTELLECTUAL

CAPITAL DISCLOSURE TERHADAP EARNING RESPONSE COEFFICIENT

(Studi Pada Perbankan Yang Listed di Bursa Negara ASEAN Tahun 2015-2016)

Erwindiawan

library dengan mengumpulkan data-data teoritis yang berasal dari buku, jurnal dan literatur yang berkaitan dengan penelitian.

Data yang digunakan dalam penelitian ini adalah data panel. Data panel adalah gabungan antara data runtut waktu (time series) dan data silang (cross section). Menurut Widarjono (2013) penggunaan data panel dalam sebuah observasi mempunyai beberapa keuntungan yang di peroleh. Dalam melakukan analisis dan pengujian hipotesis digunakan program SPSS versi 23. Metode analisis dalam penelitian ini menggunakan regresi data panel.

Model regresi data panel untuk menguji pengaruh Good Corporate Governance dan Intellectual Capital Disclosure terhadap Earning Response Coefficient dengan variabel kontrol Size, Leverage dan Growth sebagai berikut:

\section{$\mathrm{CAR}=\beta_{0}+\beta_{1} \mathrm{UE}+\beta_{2} \mathrm{GCG}+$}

$\beta_{3} \mathrm{ICD}+\beta_{4} \mathrm{UE} \mathrm{\beta}^{*} \mathrm{GCG}+\beta_{5} \mathrm{UE}^{*} \mathrm{ICD}+\beta_{6} \mathrm{SIZE}+$

$\beta_{7} \mathrm{LEV}+\beta_{8}$ GROWTH+e

Keterangan:

$\mathrm{CAR}=\quad$ Cumulative Abnormal Return

$\alpha=$ konstanta

$\beta_{1}, \beta_{2} \ldots=$ koefisien regresi

$\mathrm{UE}=$ Unexpected Earning

GCG $=$ Good Corporate Governance

ICD = Intellectual Capital Disclosure

Size $=$ Ukuran Perusahaan

Lev $=$ Leverage

GROWTH $=$ Growth

$\varepsilon=$ error

\section{HASIL DAN PEMBAHASAN}

\section{Variabel Dependen}

Variabel dependen dalam penelitian ini adalah cummulatif abnormal return. Variebel ini diproksikan dengan model crosssection, yaitu dengan menjumlahkan nilai buku per lembar saham pada periode $t$ dengan laba per saham pada periode $t+1$, kemudian dikurangi dengan harga saham pada periode $t$, lalu hasilnya dibagi harga saham pada periode $t$. Berdasarkan tabel 4.1 di atas variabel Cummulative Abnormal Return memiliki nilai rata-rata .318904, artinya rata-rata CAR adalah 31\% .

\section{Variabel Independen}

26|Pelita - Jurnal Penelitian dan Karya Ilmiah 


\section{a. Prinsip-prinsip Good Corporate Governance}

Pengukur Good Corporate Governance pada penelitian ini adalah dengan menggunakan parameter ASEAN CG scorecard, yang merupakan suatu tolak ukur atau parameter pengukuran praktek Corporate Governance yang disepakati oleh ACMF (ASEAN Capital Market Forum) yaitu asosiasi otoritas pasar modal ASEAN. Kelima prinsip-prinsip di dalamnya dijabarkan secara komprehensif ke dalam 179 pertanyaan (Level 1). Prinsip-prinsip Penerapan Good Corporate Governance dalam uji statistik deskriptif mempunyai nilai rata-rata sebesar .77228345 atau $77 \%$, artinya rata-rata perusahaan perbankan di 5 negara ASEAN yang menjadi sample penelitian ini sudah baik dalam penerapan prinsip-prinsip Good Corporate Governance. Hal ini dilihat dati indikatornya bahwa penerapan prinsipprinsip GCG sudah lebih dari 50\%, yaitu 77\%.

Nilai standar deviasi adalah sebesar .084320415 yaitu lebih kecil dari rata-rata dan lebih kecil dari plus minus 3, artinya data yang digunakan dalam penelitian ini tidak terlalu bervariasi sehingga data cukup baik untuk dijadikan sample penelitian. Nilai minimum adalah sebesar .531860 atau 53\% yaitu Public Bank Berhad Malaysia dan nilai maksimum sebesar .933087 atau 93\% yaitu pada perusahaan Bank Mandiri (Persero) Indonesia Tbk.

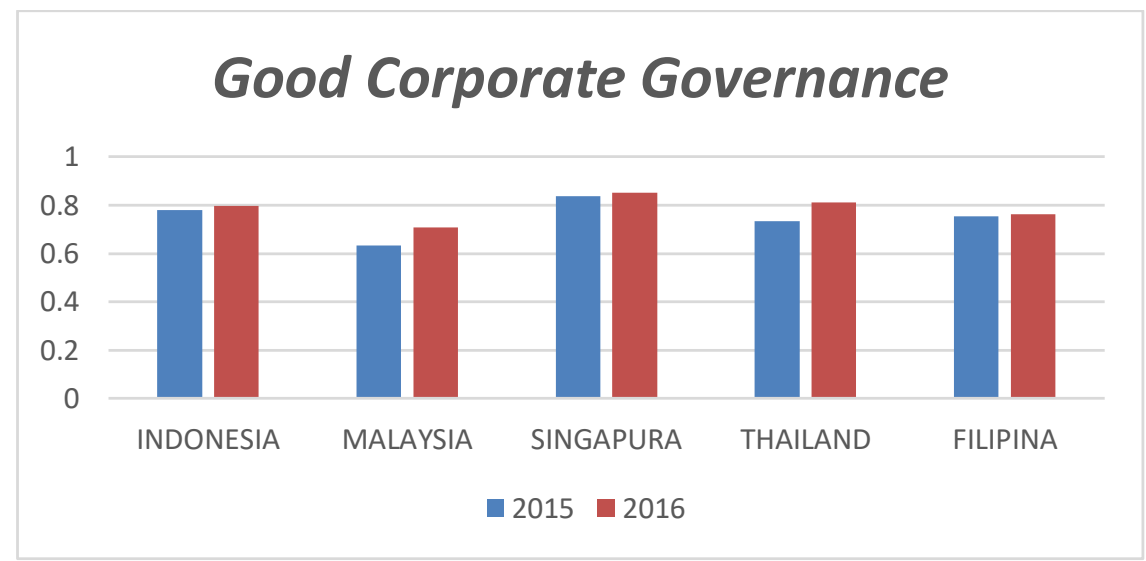

Gambar 4. Rata-rata Good Corporate Governance

Sumber: Olah data negara ASEAN 2017 
ANALISIS PENGARUH GOOD CORPORATE GOVERNANCE DAN INTELLECTUAL CAPITAL DISCLOSURE TERHADAP EARNING RESPONSE COEFFICIENT (Studi Pada Perbankan Yang Listed di Bursa Negara ASEAN Tahun 2015-2016)

\section{a) Indonesia}

\section{Erwindiawan}

Berdasarkan grafik di atas, dapat diketahui bahwa Indonesia memiliki pengungkapan Good Corporate Governance sudah sangat baik. Hal ini menandakan bahwa perusahaan perbankan di Indonesia sudah menyadari bahwa Good Corporate Governance adalah sesuatu yang penting untuk diungkapkan, karena dapat mengurangi asimetri informasi antara principle dan agent.

b) Malaysia

Berdasarkan grafik di atas, dapat diketahui bahwa Malaysia memiliki pengungkapan Good Corporate Governance sudah baik. Hal ini menandakan bahwa perusahaan perbankan di Malaysia sudah menyadari bahwa Good Corporate Governance adalah sesuatu yang penting untuk diungkapkan, karena dapat mengurangi asimetri informasi antara principle dan agent.

c) Singapura

Berdasarkan grafik di atas, dapat diketahui bahwa Singapura memiliki pengungkapan Good Corporate Governance sudah baik. Hal ini menandakan bahwa perusahaan perbankan di Singapura sudah menyadari bahwa Good Corporate Governance adalah sesuatu yang penting untuk diungkapkan.

d) Thailand

Berdasarkan grafik di atas, dapat diketahui bahwa Thailand memiliki pengungkapan Good Corporate Governance sudah baik. Hal ini menandakan bahwa perusahaan perbankan di Thailand sudah menyadari bahwa Good Corporate Governance adalah sesuatu yang penting untuk diungkapkan.

e) Filipina

Berdasarkan grafik di atas, dapat diketahui bahwa Filipina memiliki pengungkapan Good Corporate Governance sudah baik. Hal ini menandakan bahwa perusahaan perbankan di Filipina sudah menyadari bahwa Good Corporate Governance adalah sesuatu yang penting untuk diungkapkan.

\section{b. Intellectual Capital Disclosure}

Metode pengumpulan data keluasan pengungkapan Intellectual capital yang digunakan dalam penelitian ini adalah content analysis, yaitu metode pengumpulan data penelitian melalui teknik observasi dan analisis terhadap isi atau pesan dari suatu teks, kandungan (content) dari sepenggal tulisan, atau dokumen, kemudian menggolongkan ke dalam berbagai kategori atau kelompok bergantung pada kriteria yang telah ditetapkan.

28IPelita - Jurnal Penelitian dan Karya Ilmiah 
Penulis menggunakan komponen daftar pengungkapan intellectual capital yang bersumber dari Li et al,. (2008). Pendekatan yang digunakan didalam penelitian ini adalah berdasarkan indeks pengungkapan yang dibedakan dengan item skor 1 (satu) jika diungkapkan dan 0 (nol) jika tidak diungkapkan.

Intellectual Capital Disclosure merupakan suatu cara untuk mengungkapkan bahwa laporan tahunan menggambarkan aktifitas perusahaan yang kredibel dan terpadu. Hasil uji deskriptif intellectual capital disclosure, mempunyai nilai rata-rata .78369297 yang berarti rata-rata sampel emiten perbankan telah melakukan pengungkapan Intellectual Capital dalam laporan tahunan sebesar $78 \%$. Nilai rata-rata pengungkapan Intellectual Capital ini cukup besar, dengan melaporkan intellectual capital, emiten perbankan memiliki kesempatan untuk membangun kepercayaan dengan para stakeholder, meningkatkan reputasi eksternal, serta mengurangi asimetri informasi. Standar deviasinya adalah sebesar .084770785 dengan nilai minimum .606557 yaitu pada Bank Of India Indonesia Tbk tahun 2015 dan nilai maksimum sebesar .951639 pada Bank Negara Indonesia (Persero) Tbk tahun 2016.

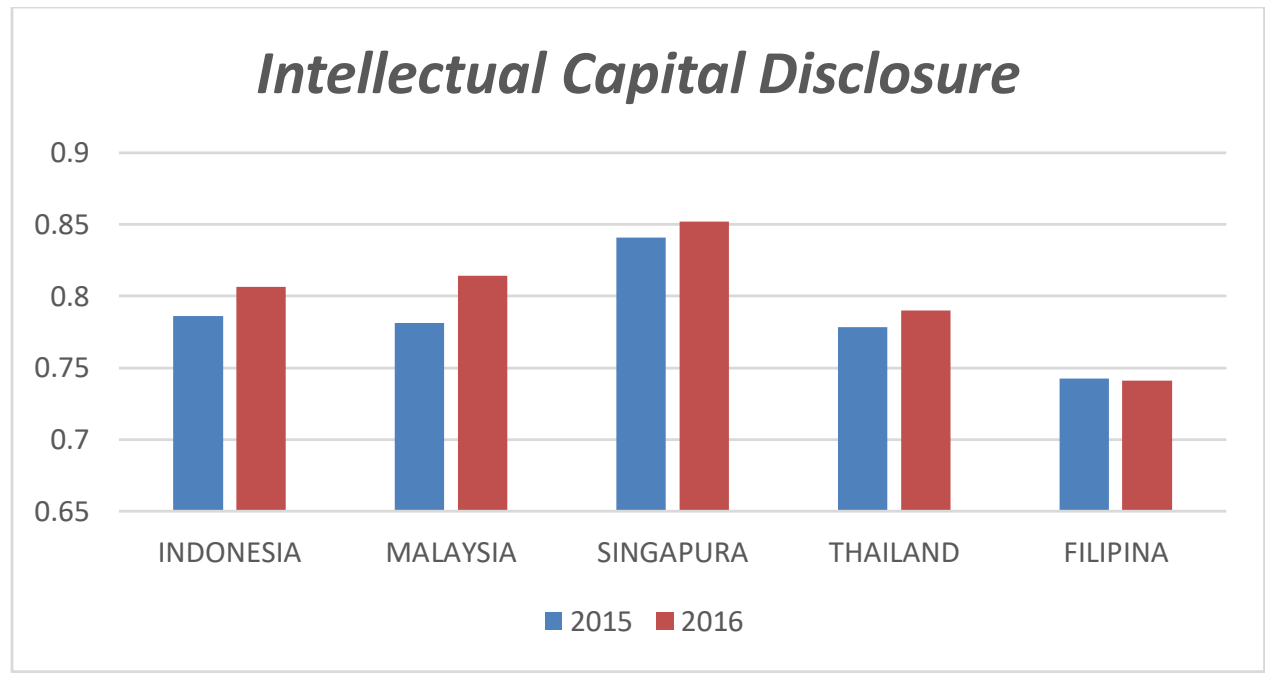

Gambar 4.2 Rata-rata Intellectual Capital Disclosure Sumber: Olah data negara ASEAN 2017 
ANALISIS PENGARUH GOOD CORPORATE GOVERNANCE DAN INTELLECTUAL CAPITAL DISCLOSURE TERHADAP EARNING RESPONSE COEFFICIENT (Studi Pada Perbankan Yang Listed di Bursa Negara ASEAN Tahun 2015-2016)

\section{a) Indonesia}

\section{Erwindiawan}

Berdasarkan grafik di atas, dapat diketahui bahwa Indonesia memiliki pengungkapan Intellectual Capital sudah baik. Hal ini menandakan bahwa perusahaan perbankan di Indonesia sudah menyadari bahwa Intellectual Capital adalah sesuatu yang penting untuk diungkapkan.

b) Malaysia

Berdasarkan grafik di atas, dapat diketahui bahwa Malaysia memiliki pengungkapan Intellectual Capital sudah baik. Hal ini menandakan bahwa perusahaan perbankan di Malaysia sudah menyadari bahwa Intellectual Capital adalah sesuatu yang penting untuk diungkapkan.

c) Singapura

Berdasarkan grafik di atas, dapat diketahui bahwa Singapura memiliki pengungkapan Intellectual Capital sudah baik. Hal ini menandakan bahwa perusahaan perbankan di Singapura sudah menyadari bahwa Intellectual Capital adalah sesuatu yang penting untuk diungkapkan.

d) Thailand

Berdasarkan grafik di atas, dapat diketahui bahwa Thailand memiliki pengungkapan Intellectual Capital sudah baik. Hal ini menandakan bahwa perusahaan perbankan di Thailand sudah menyadari bahwa Intellectual Capital adalah sesuatu yang penting untuk diungkapkan.

\section{e) Filipina}

Berdasarkan grafik di atas, dapat diketahui bahwa Filipina memiliki pengungkapan Intellectual Capital sudah baik. Hal ini menandakan bahwa perusahaan perbankan di Filipina sudah menyadari bahwa Intellectual Capital adalah sesuatu yang penting untuk diungkapkan.

Varible Control dalam penelitian ini adalah Size, Leverage, Growth dan Country. Berdasarkan tabel 4.1, variable control Size memiliki nilai minimum sebesar 7.928154, nilai maksimum 20.969385, nilai rata 17.61677533, dan standar deviasi 2.588797769. Perusahaan perbankan di 5 ASEAN tersebut memiliki nilai rata-rata aset yang cukup besar.

Berdasarkan tabel 4.1, variable control Leverage memiliki nilai minimum sebesar .414901 , nilai maksimum 1.405900 , nilai rata .81728692 , dan standar deviasi .412908998. Perusahaan perbankan di 5 ASEAN tersebut memiliki nilai leverage yang cukup besar. Berdasarkan tabel 4.1, variable control Growth memiliki nilai minimum sebesar.006303, nilai maksimum 1.095095, nilai rata .37004696, dan standar deviasi .121181346 . Nilai rata-rata pertumbuhan perusahaan sebesar $37 \%$ mengindikasikan bahwa perusahaan perbankan di 5 ASEAN tersebut memiliki pertumbuhan perusahaan yang cukup bagus.

30|Pelita - Jurnal Penelitian dan Karya Ilmiah 


\section{Pengujian Hipotesis}

\section{Uji Signifikansi Model (F-test)}

Uji F disebut juga sebagai uji serentak / bersama-sama. Uji F dilakukan untuk mengetahui apakah variabel dependen secara bersamasama dipengaruhi oleh variabel independen. Pengujian dapat dilakukan dengan melihat tingkat signifikan F.

Menurut Ghozali (2016), jika signifikansi F Stat $\leq 0.05$ maka Ho ditolak, dan Ha diterima. Sedangkan jika signifikansi F Stat $>0.05$ maka Ho diterima, dan Ha ditolak. Dari uji F akan diputuskan untuk menerima atau menolak hipotesa yang diajukan (Ghozali, 2016):

a) Bila signifikansi $\mathrm{F}$ hitung $\leq 0.05$, maka Ho ditolak dan Ha diterima. Ini berarti semua variabel independen secara bersama-sama terdapat pengaruh yang signifikan terhadap variabel dependen.

b) Bila signifikansi F hitung $>0.05$, maka Ho ditolak dan Ha diterima. Ini berarti semua variabel independen secara bersama-sama tidak terdapat pengaruh yang signifikan terhadap variabel dependen.

\begin{tabular}{|c|c|c|c|c|c|c|}
\hline & \multicolumn{6}{|c|}{$\begin{array}{c}\text { Tabel } 4.6 \mathrm{Uji}^{\mathrm{F}} \\
\text { ANOVA }^{\mathrm{a}}\end{array}$} \\
\hline & Model & $\begin{array}{l}\text { Sum of } \\
\text { Squares }\end{array}$ & Df & $\begin{array}{l}\text { Mean } \\
\text { Square }\end{array}$ & $\mathrm{F}$ & Sig. \\
\hline \multirow{3}{*}{1} & Regression & 1026,585 & 8 & 128,323 & 175,047 &, $000^{\mathrm{b}}$ \\
\hline & Residual & 100,432 & 137 & ,733 & & \\
\hline & Total & 1127,016 & 145 & & & \\
\hline
\end{tabular}

a. Dependent Variable: CAR

b. Predictors: (Constant), Growth, UE x ICD, LEV, CG, ICD, Size, UE, UE x CG

Sumber: olah data SPSS v.23 (2017)

Berdasarkan pengujian regresi pada tabel 4.6 di atas, diperoleh nilai signifikasi lebih kecil dari nilai alpha yaitu $0,000<0,05$. Dengan demiikian model regresi dapat digunakan untuk memprediksi earning response coefficient atau dapat dikatakan bahwa prinsip-prinsip penerapan Good Corporate Governance dan intellectual capital secara bersama-sama berpengaruh terhadap Cost of equity capital.

\section{Uji Koefisien Determinasi $\left(\mathbf{R}^{2}\right)$}

Koefisien Determinasi $\left(\mathrm{R}^{2}\right)$ digunakan untuk mengetahui seberapa jauh kemampuan suatu model penelitian dalam menjelaskan variasivariabel dependen yang ada. $R^{2}$ mempunyai interval antara 0 sampai $1(0 \leq$ 
$R^{2} \leq 1$ ). Semakin besar $R^{2}$ (mendekati 1) berarti variabel-variabel independen memberikan hampir semua informasi yang dibutuhkan untuk memprediksi variasi variabel dependen. Namun jika semakin mendekati 0 , maka variabel independen secara keseluruhan tidak dapat menjelaskan variabel dependen. (Ghozali, 2016).

Tabel 4.7 Uji Koefisiensi Determinasi Model Summary

\begin{tabular}{lrrrr}
\hline Model & R & R Square & $\begin{array}{c}\text { Adjusted R } \\
\text { Square }\end{array}$ & $\begin{array}{r}\text { Std. Error of } \\
\text { the Estimate }\end{array}$ \\
\hline 1 & ,611 a & ,373 &, 340 & 1,286 \\
\hline a. Predictors: (Constant), Growth, UE x ICD, LEV , CG, \\
ICD, Size, UE, UE x CG
\end{tabular}

Nilai koefisien determinasi $\left(\mathrm{R}^{2}\right)$ pada tabel 4.8 di atas sebesar 0.373 menunjukkan bahwa kemampuan variabel bebas dalam menerangkan variabel terikat sebesar $37 \%$. Dengan demikian, dapat diketahui bahwa nilai koefisien determinasi atau $R$ Square adalah 0.373 , artinya $37 \%$ variabel Cummulative Abnormal Return dapat dijelaskan oleh variabel bebas dalam model penelitian. Sedangkan sisanya $63 \%$ dijelaskan oleh variabel lain yang tidak diajukan dalam model penelitiaan ini.

\section{Uji Signifikan Parsial $\mathbf{t}(t$-test)}

Uji $\mathrm{t}$ digunakan untuk mengetahui hubungan masing-masing variabel independen secara individual terhadap variabel dependen. Uji ini dilakukan untuk mengetahui ada tidaknya pengaruh masing-masing variabel independen secara individual terhadap variabel dependen digunakan tingkat signifikansi 0.05 sebagai berikut (Ghozali, 2016): 
Edisi XIX Volume 1, Januari - Juni 2019

Jurnal Penelitian dan Karya Ilmiah

Tabel 4.8 Uji T

\section{Coefficients $^{\mathrm{a}}$}

\begin{tabular}{|c|c|c|c|c|c|}
\hline \multirow[t]{2}{*}{ Model } & \multicolumn{2}{|c|}{$\begin{array}{l}\text { Unstandardized } \\
\text { Coefficients }\end{array}$} & \multirow{2}{*}{$\begin{array}{c}\text { Standardized } \\
\text { Coefficients }\end{array}$} & \multirow[t]{2}{*}{$\mathrm{T}$} & \multirow[t]{2}{*}{ Sig. } \\
\hline & B & Std. Error & & & \\
\hline (Constant) & 978 & ,951 & & 1,028 & 306 \\
\hline UE & $-5,966$ & ,373 & $-19,821$ & $-16,015$ & ,000 \\
\hline $\mathrm{CG}$ & -820 & 902 &,- 025 &,- 909 & 365 \\
\hline$\overline{I C D}$ & ,294 & ,918 & ,009 &, 321 & ,749 \\
\hline UE $\times$ CG & 4,656 &, 562 & 11,527 & 8,284 &, 000 \\
\hline UE $\times$ ICD & 3,875 & ,153 & 8,493 & 25,251 & 000 \\
\hline Size &,- 011 &, 020 &,- 015 &,- 546 &, 586 \\
\hline LEV & , 000 & ,002 &,- 004 &,- 169 & 866 \\
\hline Growth & $-5,498 \mathrm{E}-005$ & ,001 &,- 001 &,- 049 & 961 \\
\hline
\end{tabular}

a. Dependent Variable: CAR

Sumber: olah data SPSS v.23 (2017)

Berdasarkan tabel 4.8 diatas, hasil uji $\mathrm{t}$ menunjukkan bahwa terdapat tiga variabel independen yang secara statistik mempengaruhi variabel dependen CAR yaitu UE, (UE x CG) dan (UE x ICD). Hal ini ditunjukkan oleh nilai signifikansi pada variabel tersebut lebih kecil dari nilai apha yaitu 0,05. Sedangkan variabel CG, ICD, SIZE, LEV, dan Growth tidak berpengaru terhadap CAR. Hal ini ditunjukkan oleh nilai signifikansi pada variabel tersebet lebih besar dari nilai alpha yaitu 0,05 .

\section{Uji Regresi Linear Berganda}

Berdasarkan tabel 4.6 di atas, maka dapat diketahui persamaan regresi sebagai berikut:

$\mathrm{CAR}=0.978-5.966 \mathrm{UE}-0,820 \mathrm{CG}+0.294 \mathrm{ICD}+4,656(\mathrm{UE} \times \mathrm{CG})+3.875$

\section{Dimana:}

$($ UE $x$ ICG $)+0.011$ Size 0,000 LEV- 0.000005498 Growth $+\varepsilon$

$\begin{array}{ll}\text { CAR } & =\text { Cummulatif Abnormal Return } \\ \text { UE } & =\text { Unexpected Return } \\ \text { GCG } & =\text { Good Corporate Governance yang didapat dari } \\ & \text { ASEAN CG Scorecard } \\ \text { ICDI } & =\text { Intellectual capital disclosure index } \\ \mathrm{a}_{0} / \beta_{0} & =\text { konstanta } \\ \varepsilon & =\text { error }\end{array}$


ANALISIS PENGARUH GOOD CORPORATE GOVERNANCE DAN INTELLECTUAL CAPITAL DISCLOSURE TERHADAP EARNING RESPONSE COEFFICIENT (Studi Pada Perbankan Yang Listed di Bursa Negara ASEAN Tahun 2015-2016)

\section{Erwindiawan}

a) Konstanta sebesar 0.978. Hal ini menyatakan bahwa jika tidak ada variable UE, ICD, (UE x CG), (UE x ICG), Size, LEV dan Growth tetap akan konstan sebesar nilai konstanta tersebut. Dengan kata lain apabila variabel independen dalam model diatas diasumsikan sama dengan 0 nilainya atau konstan, maka nilai rata-rata keputusan investasi akan bertambah sebesar 0.978 .

b) Koefisien regresi pada variable UE sebesar -5,966. Artinya terdapat pengaruh negatif variabel UE terhadap CAR. Dengan demikian setiap kenaikan satu poin variabel UE akan mennurunkan variabel CAR sebesar 5,966 point.

c) Koefisien regresi pada variabel (UE x CG) sebesar 4,656. Artinya terdapat pengaruh positif variabel (UE x CG) terhadap CAR. Dengan demikian setiap kenaikan satu poin variabel (UE $\times$ CG) akan meningkatkan variabel CAR sebesar 4,656 point.

d) Koefisien regresi pada variabel (UE x ICD) sebesar 3.875. Artinya terdapat pengaruh positif variabel (UE x ICD) terhadap CAR. Dengan demikian setiap kenaikan satu poin variabel (UE $x$ ICD) akan meningkatkan variabel CAR sebesar 3,875 point.

\section{PEMBAHASAN}

\section{Pengaruh Intelectual Capital Disclosure terhadap Earning Response Coefficient}

Hipotesis pertama $\left(\mathrm{H}_{1}\right)$ yang diajukan dalam penelitian ini menyatakan bahwa Intellectual Capital Disclosure berpengaruh terhadap Earning Response Coefficient. Berdasarkan uji $\mathrm{t}$ di atas, Sig < 0.1, artinya marginally significant, maka hipotesis pertama diterima, artinya Intelectual Capital Disclosure berpengaruh terhadap Earning Response Coefficeint.

Penelitian sebelumnya, Boujelbene dan Affes (2013) mengemukakan bahwa terdapat hubungan signifikan negatif antara pengungkapan dua elemen pengungkapan modal intelektual dengan Earning Response Coefficient. Penelitian ini meneliti pengaruh masingmasing komponen modal intelektual (human capital, structural capital dan relational capital) terhadap biaya modal ekuitas perusahaan-perusahaan yang terdaftar di Indeks SBF Bursa Efek Perancis. Hal ini sesuai dan sejalan dengan teori dan penelitian terdahulu, bahwa semakin besar pengungkapan modal intelektual, maka semakin besar Intellectual Capital Disclosure maka akan mengurangi asimetri informasi sehingga dampaknya akan menurunkan biaya modal yang dikeluarkan oleh investor. Maka dapat diartikan bahwa Intellectual Capital Disclosure adalah sesuatu yang penting untuk diungkapkan karena dapat menurunkan cost of equity capital. 
Berdasarkan hasil penelitian, maka penelitian ini dapat membuktikan bahwa Intellectual Capital Disclosure harus diperhatikan oleh investor karena mampu menjembatani atau mengurangi asimetri informasi yang ada antara principal dan agen sehingga dapat menaikkan Earning Response Coefficient.

\section{Pengaruh Good Corporate Governance terhadap Earning Response Coefficient}

Hipotesis pertama $\left(\mathrm{H}_{2}\right)$ yang diajukan dalam penelitian ini menyatakan bahwa Pengungkapan Good Corporate Governance berpengaruh terhadap Earning Response Coefficient. Berdasarkan uji t di atas, Sig < 0.05, maka hipotesis pertama diterima, artinya Good Corporate Governance berpengaruh terhadap Earning Response Coefficient.

Pada grafik di atas terlihat bahwa Good Corporate Governance berpengaruh positif terhadap Earning Response Coefficient. Hal ini sesuai dengan agency theory, bahwa Good Corporate Governance dapat mengurangi asimetri informasi sehingga dampaknya akan menaikkan ERC. Hal ini sesuai dan sejalan dengan teori, bahwa semakin besar penerapan prinsipprinsip Good Corporate Governance, maka akan mengurangi asimetri informasi.

\section{Implikasi}

Implikasi dari temuan empiris penelitian ini adalah Implikasi teori terkait dengan implementasi masalah keagenan dan dampak pengungkapan khususnya emiten perbankan di 5 Negara ASEAN dalam menjelaskan kebijakan penerapan good corporate governance, intellectual capital disclosure dan Earning Response Coeficient. Intellectual capital disclosure ternyata memberikan pengaruh terhadap Earning Response Coeficient pada perusahaan perbankan, hasil sejalan dengan teori dan beberapa penelitian terdahulu yang telah ada. Hasil penelitian ini menunjukan bahwa dalam kasus pengungkapan modal intelektual secara sukarela di perusahaan perbankan berpengaruh terhadap Earning Response Coeficient. Hal ini dikarenakan Informasi di dalam annual report berfungsi bagi investor sebagai pengambilan keputusan. 
ANALISIS PENGARUH GOOD CORPORATE GOVERNANCE DAN INTELLECTUAL CAPITAL DISCLOSURE TERHADAP EARNING RESPONSE COEFFICIENT (Studi Pada Perbankan Yang Listed di Bursa Negara ASEAN Tahun 2015-2016)

\section{REFERENSI}

\section{Erwindiawan}

Ambarwati, S. (2008). Earnings Response Coefficient. Jurnal Akuntabilitas, Vol. 7, No. 2, hal.128-134.

Arfan, M., dan Antasari, I. (2008). Pengaruh Ukuran, Pertumbuhan, dan Profitabilitas Perusahaan terhadap Koefisien Respon Laba pada Emiten Manufaktur di Bursa Efek Jakarta. Jurnal Telaah \& Riset Akuntansi, Vol.1, No. 1, hal.50-56.

Ball, R., dan Brown, P. (1968). An Empirical Evaluation of Accounting Income Number. Journal of Accounting Research, Vol. 6, No. 2, Autumn, 1968.

Boediono, G. S. B. (2005). Kualitas Laba: Studi Pengaruh Mekanisme Corporate Governance dan Dampak Manajemen Laba dengan Menggunakan Analisis Jalur.Simposium Nasional Akuntansi VIII. Solo.

Buku Ekuitas: Studi pada Perusahaan Manufaktur di Bursa Efek Jakarta". Simposium Nasional Akuntansi IX Padang.

Bruegger, E., dan Dunbar, F. C. (2009). Estimating Financial Fraud Damages with Response Coefficients. The Journal of Corporation Law, Vol. 35, No. 1.

Cerbioni, F., dan Parbonetti, A. (2007). Exploring The Effects of Corporate Governance on Intellectual Capital Disclosure: An analysis of European Biotechnology Companies. European Accounting Review 16(4), 791-826.

Cho, J. Y., dan K. Jung. (1991). Earning Response Coefficient: A Synthesis of Theory and Empirical Evidence. Journal of Accounting Literature, Vol. 10, No. 2.

Fidyati, N. (2003). Faktor-Faktor yang Mempengaruhi Kebijakan Hutang Perusahaan. Jurnal Ekonomi, Manajemen dan Akuntansi Vol. 1 No. 1 Januari, pp. 17-34.

Forum for Corporate governance in Indonesia. (2001). Peranan Dewan Komisaris dan Komite Audit dalam Pelaksanaan Corporate governance (Tata Kelola Perusahaan). Jilid II, Edisi Kedua, Jakarta: FCGI.

Organization for Economic Cooperation and Development. (2004). “OECD Principle of Crporate Governance". Paris: OECD Publication Service.

Mulyani, S., Asyik, N. F., dan Andayani. (2007). Faktor-faktor yang Mempengaruhi Earnings Response Coefficient pada Perusahaan yang Terdaftar di Bursa Efek Jakarta, Jurnal Akuntansi dan Auditing Indonesia, Vol. 11, No. 1, hal.35- 45. 
Murwaningsari, E. (2009). Hubungan Corporate Governance, Corporate Social Responsibilities dan Corporate Financial Performance dalam Satu Continuum. Jurnal Akuntansi dan Keuangan, Vol. 11, No. 1, pp. 30-41.

Naimah, Z., dan Utama, S. (2006). "Pengaruh Ukuran Perusahaan, Pertumbuhan, dan Profitabilitas Perusahaan terhadap Koefisien Respon Laba dan Koefisien Respon Nilai.

Sayekti, Y., dan Wondabio, L.S. (2007). Pengaruh CSR Disclosure terhadap Earning Response Coefficient. Simposium Nasional Akuntansi X, 2628 Juli. Makasar.

Scott, W. R. (2000). Financial Accounting Theory. Second edition. Canada: Prentice Hall.

Scott, W. R. (2009). Financial Accounting Theory. 5th edition. Canada: Prentice Hall.

Suwardjono. (2005). Teori Akuntansi dan Perekayasaan Pelaporan Keuangan. Yogyakarta: BPFEYOGYAKARTA.

Tuwentina, P., dan Wirama, D. G. (2014). Pengaruh Konservatisme Akuntansi dan Good Corporate Governance pada Kualitas Laba. EJurnal Akuntansi Universitas Udayana. Vol. 8, No. 2.

Ummah, H. (2012). "Analisa Pengaruh Penyusutan Terhadap Earnings Response Coefficient (ERC) pada Perusahaan yang terdaftar di Bursa Efek Indonesia", Fakultas Ekonomi, Universitas Indonesia, Depok, 2012.

Ujiyantho, A.M., dan Pramuka, B.A. (2007). "Mekanisme Corporate Governance, Manajemen Laba dan Kinerja Keuangan." Simposium Nasional Akuntansi X, 26-28 Juli. Makasar.

Wahyudianawati. (2005). "Pengaruh Free cash Flow, Kepemilikan Manajerial dan Growth Opportunity terhadap Kebijakan Utang pada Perusahaan Manufaktur yang listing di B $\mathrm{J}^{\prime \prime}$. Skripsi. Fakultas Ekonomi Universitas Airlangga.

Yunita, F., Wenny, P., dan Tumpal JRS. (2008). "Menentukan Variabel yang Secara Signifikan Mempengaruhi Koefisien Respon Laba Industri Manufaktur yang Terdaftar di BEI", ISSN: 0854 - 8153. Vol. 15, No. 1, hal.21-30. 